\title{
IAMJ
}

INTERNATIONAL

AYURVEDIC

MEDICAL JOURNAL

Review Article

ISSN: 2320-5091

Impact Factor: 6.719

\section{A CRITICAL ANALYSIS ON THE RELATIONSHIP BETWEEN VRIKKA, YAKRITA AND HRIDAYA IN THE PATHOGENESIS OF VRIKKA ROGA AND ITS UPADRAVA W.S.R TO CHRONIC KIDNEY DISEASE}

\author{
$\underline{\text { Priyanka Chakraborty }}^{1}, \underline{\text { Om Prakash Gupta }}^{2}, \underline{\text { Ranjan Kalita }}^{3}$ \\ ${ }^{1}$ PG Scholar, ${ }^{2}$ Professor, ${ }^{3}$ Lecturer \\ Department of Kayachikitsa, Government Ayurvedic college and hospital, Jalukbari, Kamrup (M), Guwahati, \\ Assam - 781014, India
}

Corresponding Author: priyankachakraborty.604@gmail.com

\begin{abstract}
https://doi.org/10.46607/iamj3909092021
\end{abstract}
(Published Online: September 2021)

Open Access

(C) International Ayurvedic Medical Journal, India 2021

Article Received: 25/08//2021 - Peer Reviewed: 04/09/2021 - Accepted for Publication: 05/09/2021

\section{Check for updates}

\begin{abstract}
Chronic Kidney Disease is a chronic progressive declination in the function of kidneys with serious and dreadful complications which result in low life expectancy of the sufferer, and it can be correlated to as an amalgamation of the pathology related to Rasa Pradosaj vikar, Kaphaj sotha, Pandu, Mutrakriccha, Mutraghata, Prameha and its complications which are called as Vrikka roga (Kidney diseases). The literary data have been collected from Charak Samhita, Sushruta Samhita, Ashtanga Hridaya, Ashtanga Sangraha and Sharangadhar Samhita. The collected literature have been analysed to justify that there may be a vast relationship between Vrikka (Kidneys), Yakrita (Liver) and Hridaya (Heart) in the pathogenesis of Vrikka roga (Kidney diseases) and its Upadrava (complications). The analysis establishes that Vrikka roga (Kidney diseases) is one of the Vataj Nanatmaja Roga and Meda Dhatu (Fat tissue) is the prime Dhatu (tissues) that gets vitiated and the aggravated Abaddha Meda (free fatty acids) results the pathogenesis of Vrikka Roga (Kidney diseases) alongwith Rakta (blood). Whereas, Rakta (blood) is seen being the Pradhan Dhatu involved in the pathogenesis of Vrikka Roga Upadrava. Therefore, an inference can be drawn that for slowing the progression of the pathogenesis and evolvement of complications, aggravated Abaddha Meda Chikitsa, Rakta Dhatu Poshak and ignition of the Dhatwagni may be adopted.
\end{abstract}


Keywords: Chronic Kidney disease, Vrikka roga, Upadrava, Rakta, Abaddha Meda, Vataj Nanatmaja Roga

\section{INTRODUCTION}

The Garbha (embryo) is formed from the Sanyoga (combination) of Shukra(sperm) and Artava (ovum) ${ }^{[1]}$. The Shukra (sperm) and Artava(ovum)are the Garbhautpadak Bija. During the embryological period, the Anga-Pratyanga are formed from the Garbhautpadak Bija or the Bijabhaga. If the Bija or Bijabhaga is Dushita, the Anga (body parts) which will be formed also be Vikrita. This clearly shows that not only the formation of Sharira Avayavah (organs) depends on the characteristics of Bija or Bijabhaga but also the formation of disease in the later period of life. ${ }^{[2]}$

Agni (fire) is said to be Poshak (nutrient) of Pranadi Vayu and Dhatu. If 13 types of Agni are in the balanced state, then Aharapaka (food metabolism) and Dhatupaka (tissue metabolism) will also be at a normal level. ${ }^{[3]}$ This will result in proper nourishment of the dhatus in actual amount. The nourished Dhatu residing in their Srotas (channels)will help in the nourishment of the other succeeding Dhatus. ${ }^{[4]}$

For the progression of the disease, Vata is said to be the prime cause of Utpatti. Dhatu kshay (tissue loss) and Avarana are the main reason for Vayu Prakopa. ${ }^{[5]}$ The Dhatu or the Avayava (organs) which is being formed from the constitution of Guru (heavy), Snigdha (unctuous), etc. guna (qualities) gets depleted. This depletion of the Dhatu or the Avayavah results Sthansamshraya of the increased Vata. The Sthansamshraya (stage of pathogenesis) in that particular area leads to Vriddhi or Kopa of Vayu. ${ }^{[6]}$

During the Prasara stage of every disease, the vitiated or aggravated Doshas enter the Rasayani (Dhamani or Sira) of that particular Rogadhisthan Anga and result in Vyadhi Nirman (disease formation). ${ }^{[7][8] ~ P r a k r i t ~}$ karma of Vyana Vayu is Viksepana (abnormal movement) of Dhatu throughout the body. In Vyadhi Nirman, the Kha Vaigunya is already present in the respective Ashaya. Here, as Kha Vaigunya gets obstructed, it gives rise to Vyadhi. ${ }^{\text {[9][10] }}$

After the development of the disease, the Upadrava of the disease occurs. The Upadrava may be the Ashrita of Pradhan Roga where it is arising from. The development of another disease based on the pathogenesis of the Pradhan Roga is known as Upadrava. ${ }^{[11]}$ Sometimes, Upadrava and Pradhan Roga occur simultaneously in the body. This is called as Ubhayarthakari Vyadhi Sankara. ${ }^{[12]}$ Even the Doshic or Dhatuj involvement is common for the Pradhan Roga and the Upadrava, but the site of development is different from each other.

\section{Chronic Kidney Disease}

CKD (Chronic Kidney Disease) encompass a spectrum of different pathophysiological process associated with abnormal kidney function and progressive decline in glomerular filtration rate (GFR) along with hyper infiltration and hypertrophy of the viable nephrons. It leads to long term reduction of renal mass irrespective of the underlying aetiology. In progressive stages, the building up of innumerable toxins in the renal blood flow is characterised by Uremic syndrome which leads to Vasculopathy. ${ }^{[13]}$ When the kidneys get affected and start progressing to other stages with declination in eGFR, the other mechanism of the body also gets affected. CKD is a complex disease. The circulatory system of the body-systemic, portal, pulmonary, renal all gets messed up. This led to the pathogenesis of several complications like anaemia, metabolic disorders, bone disease, heart disease, electrolyte imbalance, etc. As CKD progresses, the vascular involvement of systemic, portal and renal circulation occurs at a greater pace, which eventually leads to the development of several severe complications.

Vrikka roga According to Ayurveda, Vrikka Roga can be defined as an amalgamation of Lakshan of several diseases like Rasa pradosaj vikar, Kaphaj Sotha, Pandu, Mutrakriccha, Mutraghata, Prameha and its upadrava. The Dosha Prakopak Hetu like Nidanarthakara Roga, Santarpanjanya, Apatarpanjanya and Ajeerna Avastha leads to Agni Dushti and therefore vitiation of Samana Vayu, Pachak Pitta and Ranjak Pitta occurs with the aggravation of Kledak Kapha. The Prakupita Dosha gets Sthansamshraya in Vrikka and 
Mutrasaya through Vyan Vayu leading to Srotadushti of Dhatus, Mala and Oja which results in Apana Vayu vitiation. ${ }^{[14]}$ This directs to the pathogenesis of Vrikka Roga.

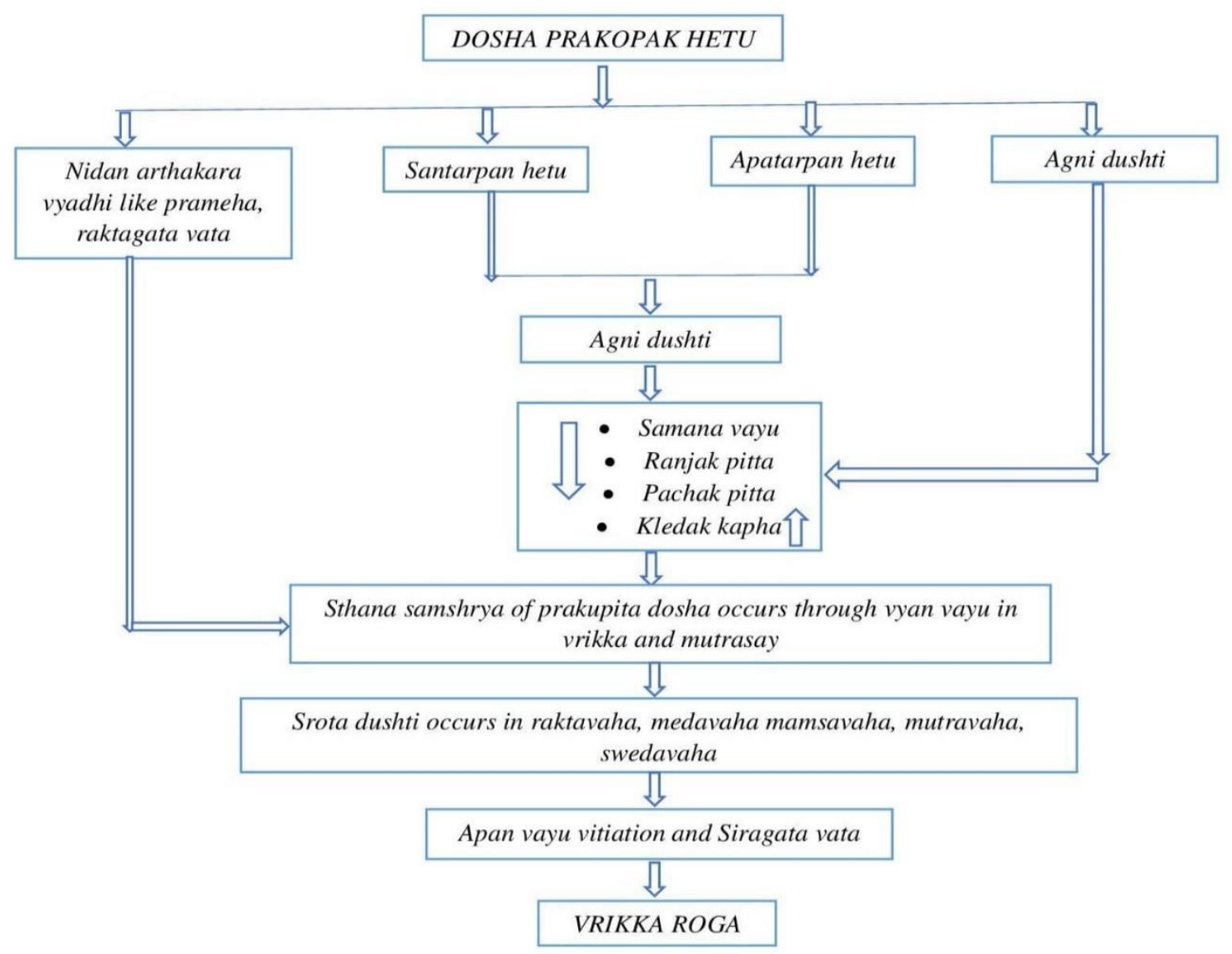

Fig. Samprapti of Vrikka Roga

\section{Samprapti Ghatak}

Dosha: Tridosha, Vata Pradhan

Dushya: Rasa (plasma), Rakta (blood), Abaddha Meda (free fatty acids)

Srotas Involved: Rasa (plasma), Rakta (blood), Mamsa (muscle), Meda (fat tissue), Asthi (bone tissue), Majja (bone marrow), Shukra (reproductive tissue), Sweda (sweat), Mutra (urine), Prana, Anna, Udaka, Oja

Adhisthan: Vrikka (kidneys), Vasti (urinary bladder), Sarva sharir (whole body)

Srota dushti: Sanga

Agni: Dhatwagni

Swabhava: Chirakari (chronic)

Sadhya-asadhyata: Yapya/Asadhya

\section{VRIKKA (KIDNEYS)}

\section{Garbha Sharira}

According to Sushruta, Vrikka is developed from the Prasad Bhag or Sara of Rakta and Meda. ${ }^{[15]}$ Vrikka is one of the Matrija Bhava. ${ }^{[16]}$

\section{Rachna Sharira}

Vrikka is two in numbers and looks like Mamsa Pinda. One is situated in the Bamaparshwa (left flanks) and the other is in Dakshinaparshwa (right flanks). ${ }^{[17]}$ Dalhan has also mentioned that it has a round nodular shape. It is said to be one of the Mulasthan of Medavaha srotas. ${ }^{[18]}$ Basti Marma is one of the Tri-marma mentioned in Ayurveda. ${ }^{[19]}$ It resides in the Katipradesh, and it is Mamsa and Shonita Yukta. It is the Sthan of Mutra. It not only structurally signifies Basti 
(urinary bladder) but also considers the whole Vrikka (renal function).

\section{Kriya Sharira}

Vrikka gives nutrition to the Jatharasta Meda. ${ }^{[21]}$

\section{Mutra and Mutravaha Srota}

Mutra is the Dravarupi Kitta produced as a result of Aharapak and is stored in the Mutrasay. ${ }^{[22]}$ According to Adhyamala in Sharangadhar Tika, Ahara Jalavahi sira resides in the Vrikka which then passes out through Dhamani from the Mutrasay(urinary bladder). The Adhogami Dhamani transports Apan Vayu, Mutra (urine), Purisha(faeces), Shukra(sperm) and Artava(ovum)in a downward direction. The Mutravaha Dhamani extends from the level of Nabhi (umbilicus) and goes towards the Basti and thereby transportation of Mutra occurs. ${ }^{[23]}$

\section{YAKRITA (LIVER)}

\section{Garbha Sharira}

Yakrita (Liver) is formed from the Rakta Sara. ${ }^{[24]}$ It is one of the Matrija Bhava. ${ }^{[25]}$

\section{Rachna Sharira}

Yakrita is situated below Hriday but on the right side of the body. ${ }^{[26]}$ Along with Pleeha (Spleen), Yakrita can be considered as Shonitashay for the formation of Rakta. ${ }^{[27]}$ It is one of the Mulasthan for Raktavaha Srotas $^{[18]}$. It is one of the Koshthanga ${ }^{[28]}$ and is the main site of Ranjak Pitta. ${ }^{[2]}$ The Raktadhara Kala resides over the Sira, Yakrita and Pleeha and the circulation of Rakta occurs. ${ }^{\text {[30] }}$

\section{Kriya Sharira}

The Prasadabhuta Rasa and the Kittamsa which has been formed after the Ahar Pachan goes to the Yakrita and gets Ragakrita. The Prasadbhuta Rasa transforms to Rakta and Kittamsa after being Ranjita gets transformed to Mala and Mutra. ${ }^{\text {[29] }}$

\section{Rakta Dhatu and Raktavaha Srota}

Rakta is one of the Saptadhatu and according to Sushruta, it is the fourth Dosha. Rakta Dhatu is formed by a process in which Ushna Guna of Pitta acts as on Rasa Dhatu and it converts Rasa Dhatu into Rakta Dhatu by Ranjan Karma. ${ }^{[29]}$ Rakta Dhatu is Anushnasheeta(neither so hot nor so cold), Snigdha(unctuous),Madhura(sweet),Guru(heavy) and Visra(foul smell). ${ }^{[31]}$
In Hemadri commentary of Ashtanga Hridaya, it has been said that Pitta has Ashrayashrayi Bhava with Rakta Dhatu. So, if there are Pitta Dushti, then the Shuddha Rakta will be affected and vice versa. According to Charaka Samhita, if there is a loss of Rakta Dhatu, there will also be a loss of other succeeding and Agni and as a result, Vata Prakopa occurs. It is explained that if a person is having Prasanna Atma, Indriya and Varna with proper Jatharagni and proper excretion of Mala and Mutra, it indicates that Rakta Dhatu is functioning normally. Such individuals are known as Vishuddha Rakta Purusha. It is the unique characteristic of Rakta Dhatu over other Saptadhatus. ${ }^{[32][33]}$

Raktavaha Srotas are the channels involved in blood formation, circulation and functioning of Rakta. Yakrita, Pleeha and Raktavaha Dhamani are the $\mathrm{Mu}$ lasthan of Raktavaha Srota. ${ }^{[34]}$

\section{HRIDAYA (HEART)}

\section{Garbha Sharira}

Hridaya (Heart) is originated from Rakta and Kapha Sara and thereby develops into a muscular organ. ${ }^{[15]}$ During Anga-Pratyanga formation, Hridaya is Matrija Bhava. ${ }^{[16][35]}$

\section{Rachana Sharira}

Hridaya is located above Pleeha and below Phupphusa on the left and to the right above Yakrita and Kloma ${ }^{[15]}$ Hridaya is the site of Chetana and the seat of Oja ${ }^{[36]}$ Along with Vrikka, it is one of the Dasha Vishesha Pranayatana ${ }^{[37]}$ It is one of the Trimarma,${ }^{[19]}$ type of Sira Marma ${ }^{[38]}$ and Sadyapranahara Marma. ${ }^{[39]}$ The shape of Hridaya is like a lotus facing Adhomukha. During Jagritavastha, Hridaya gets excited and Vikasita but in Nidravastha, it gets Sankochita. $^{[40]}$

\section{Kriya Sharira}

Hridaya is the Ashraya of Pranavaha Dhamani. ${ }^{[15]}$ It provides Rasa, Rakta and Oja to the entire Srota of the body through its Dhamani. ${ }^{[41]}$ The Prasadbhuta Ahara is converted to Rasa after digestion and absorption under the action of Pachakagni and Rasagni. ${ }^{[42]}$ Hridaya which is the Sthan of Rasa circulates the Rasa with the help of Vyan Vayu through its Dhamani to the entire body and nourishes the other Dhatus. ${ }^{[43][44]}$ 
Hridaya is said to be the seat of Rakta. ${ }^{[42]}$ Hridaya itself being a muscular organ derives its nutrition from Rasa and Rakta and vital energy from Oja. ${ }^{[45]}$ According to Nadigyanam, Hriday Gati is based upon the proper circulation of Rasa and Rakta. There are two types of Hridaya Gati- Sankochatmaka and Vikasatmaka. During the Sankocha and Vikasa, the Vega which comes from the Rakta under the action of Vayu results Sphurana or Spandana (palpitations) in the Dhamani.

\section{Meda and Medovaha Srotas}

The normal Dhatupaka occur due to the sufficient ignition of their respective Dhatwagni. Rasa when gets converted to Mamsa which again under the action of Mamsagni turns to Meda Dhatu which is Snigdha and having characteristics similar to Kapha. Kapha and Meda are having Ashraya-Ashrayee Bhava, where Kapha is Ashraya and Meda is Ashrayee. Meda is divided into Poshya and Poshaka Meda Dhatu. Poshaka Medadhatu is Asthayi (Abaddha Meda) and is circulating in the whole body with other Dhatus to nourish the Sthayi (Baddha Meda) or Poshya Meda Dhatu. It is formed in the Medodhara Kala and with the action of Medagni, it transforms to Asthi Dhatu. when Dhatwagni function is reduced, the Asthayi or Abaddha Meda Dhatu increases resulting Roga. ${ }^{[46]}$

Medavaha Srotas carry the Asthayi Meda Dhatu to transform to form the Sthayi Meda Dhatu. ${ }^{[47]}$ The Mula of Medavaha Srotas are Vrikka and Vapavahana, ${ }^{[48]}$ Vrikka and Kati; ${ }^{[49]}$ Vrikka and Mamsa. ${ }^{[50]}$

\section{DISCUSSION}

Relationship between Vrikka, Yakrita and Hridaya in the pathogenesis of Vrikka roga

The Mula of Rasavaha Srota is Hridaya. ${ }^{[18]}$ The Prasadbhuta Ahara Rasa circulates through the Dhamanis to the other Avayava, Dhatu and Upadhatu from Hridaya and gives nourishment. But, when Hridaya gets diseased, according to the Dhatu Poshan Nyaya, this function gets hindered leading to improper functioning of other Dhatus. The succeeding Dhatus like Rakta, Mamsa, Meda, etc. gets vitiated and start developing disease. The excess formation of Abaddha Meda occurs during this phase which pollutes the Meda Sara resulting various diseases and one of them is Vrikka Roga. According to modern pathology, this type of Vrikka Roga can be correlated with Cardio-renal syndrome.

Due to the formation of Abaddha Meda in Hridaya and Kha Vaigunya, the process of nourishment of the Dhatus and Srotas get obstructed leading to Dhatu Kshay and Oja Kshay. The Rakta which is formed in the Yakrita do not form adequately leading to Karmahani of Yakrita. Following this, the vitiation of Raktavaha Srotas and Medavaha Srotas occur resulting in improper nourishment of the Vrikka resulting Vrikka Roga and modern pathology terms, it can be correlated as Hepato-renal syndrome.

Relationship between Vrikka, Yakrita and Hridaya in the pathogenesis of Vrikka roga upadrava

Vrikka is developed from Rakta and Meda Sara. The Yakrita is the Mula Sthan for Raktavaha Srotas. Yakrita produces Rakta with the help of Ranjak pitta and thereby circulates it through Raktavaha srotas. When Vrikka gets affected, Yakrita due to the vitiation of Raktasara also gets affected.

Following the vitiation of Yakrita and its constituents, the formation of Shuddha Rakta gets obstructed. Therefore, Ashuddha Rakta gets circulated through Raktavaha Srotas and Vyan Vayu vitiation occurs in Hridaya. It causes failure in the Sankocha and Vikasa of Hridaya resulting Hridroga. Hridaya is known to be the sthana of Oja. Any disequilibrium in Hridaya can lead to Oja Kshay and even death. On the other hand, both Vrikka and Hridaya develop from Rakta Sara. So, when Vrikka gets deranged due to several Hetu, Hridaya also gets affected because of the vitiation of Rakta Sara.

The Pradhan Doshic involvement is Vata and can be enumerated under Vataj Nanatmaja Vyadhi. The Dhatu which is specifically involved in the pathogenesis of Vrikka Roga Upadrava is the Rakta. The vitiation of Rakta Dhatu due to improper formation of Rasa and Rasagni leads to the vitiation of other Dhatus, Upadhatus and mala.

Due to the Ashray-Ashrayi Sambandha of DoshaDhatu-Mala, Tridosha vitiation lead to the manifestation of several Upadrava related to vrikka Roga. 
Embryologically, Rakta being one of the main components in the formation of Vrikka, Yakrita and Hridaya. Therefore, with the other Dhatus getting involved, Rakta can be said to be the prime Dhatu for the exposure of serious Lakshan in Vrikka Roga. Vrikka, Yakrita and Hridaya are interrelated to each other in the pathogenesis of Vrikka Roga Upadrava due to the vitiation of Rasa, Rakta and Raktavaha Dhamani.

Vrikka Roga and its Upadrava remain simultaneously in the body, though the former is the cause of another disease and is still not being cured. This can be called Ubhayarthakary Vyadhi Sankara.

\section{CONCLUSION}

With this study, an inference can be drawn that there is a vast relationship between Vrikka, Yakrita and Hridaya in the pathogenesis of Vrikka Roga Upadrava, where Vata is the Pradhan Dosha and Rakta Dhatu is seen to be the prime Dhatu involved. Vrikka Roga is not only limited to Vrikka but it attacks the whole body progressively.

Therefore, for the management of Vrikka Roga and to slow the progression to further Upadrava, Rakta Dhatu Poshan and Chikitsa should be adopted. It can be done either by proper nutritional diet which will increase the Rasa Poshan or by igniting the Dhatwagni which may result in slowing the progression of renal failure.

\section{REFERENCES}

1. Agnivesha. Charaka Samhita, Savimarsha vidyotini, Edited by Pandit Kashinath Shastri, Dr Gorakhnath Chaturvedi. Sharira sthan, Chapter 4, sloka 5. Chaukhambha Prakashani, 2017

2. Agnivesha. Charaka Samhita, Savimarsha vidyotini, Edited by Pandit Kashinath Shastri, Dr Gorakhnath Chaturvedi. Sharira sthan, Chapter 3, sloka 17. Chaukhambha Prakashani, 2017

3. Agnivesha. Charaka Samhita, Savimarsha vidyotini, Edited by Pandit Kashinath Shastri, Dr Gorakhnath Chaturvedi. Sutra sthan, Chapter 27, sloka 342. Chaukhambha Prakashani, 2017

4. Agnivesha. Charaka Samhita, Savimarsha vidyotini, Edited by Pandit Kashinath Shastri, Dr Gorakhnath Chaturvedi. Chikitsa sthan, Chapter 8, sloka 39. Chaukhambha Prakashani, 2017
5. Agnivesha. Charaka Samhita, Savimarsha vidyotini, Edited by Pandit Kashinath Shastri, Dr Gorakhnath Chaturvedi. Siddhi sthan, Chapter 1, sloka 38-40. Chaukhambha Prakashani, 2017

6. Agnivesha. Charaka Samhita, Savimarsha vidyotini, Edited by Pandit Kashinath Shastri, Dr Gorakhnath Chaturvedi. Sutra sthan, Chapter 12. Chaukhambha Prakashani, 2017

7. Vriddha Vagbhata. Ashtanga Sangraha. Edited by Dr Ravidutta Tripathi. Nidan sthan, Chapter 1, sloka 30. Chaukhambha Prakashani, 2018.

8. Vagbhata. Ashtanga Hridayam. Commentator Kaviraj Atridev Gupta. Nidan sthan, Chapter 1, sloka 23. Chaukhambha Prakashani, 2018.

9. Agnivesha. Charaka Samhita, Savimarsha vidyotini, Edited by Pandit Kashinath Shastri, Dr Gorakhnath Chaturvedi. Chikista sthan, Chapter 15, sloka 36. Chaukhambha Prakashani, 2017

10. Sushruta. Sushruta Samhita. Ayurveda Tattwa Sandipika. Edited by Kaviraja Ambikadutta Shastri. Sutra sthan, Chapter 24, sloka 10. Chaukhambha Prakashani, 2015.

11. Agnivesha. Charaka Samhita, Savimarsha vidyotini, Edited by Pandit Kashinath Shastri, Dr Gorakhnath Chaturvedi. Chikitsa sthan, Chapter 21, sloka 40. Chaukhambha Prakashani, 2017

12. Agnivesha. Charaka Samhita, Savimarsha vidyotini, Edited by Pandit Kashinath Shastri, Dr Gorakhnath Chaturvedi. Nidan sthan, Chapter 8, sloka 22-21. Chaukhambha Prakashani, 2017

13. Turner Neil et al. Oxford textbook of clinical nephrology, $4^{\text {th }}$ edition. Oxford University Press, 2016;7391195.

14. Vd. Mrs. Swarupa M. Bhujbal. The Aetiopathological Study of Chronic Renal Failure with Ayurveda Perspective. PhD Thesis 2009-2012. Tilak Maharashtra Vidyapeeth, Maharashtra

15. Sushruta. Sushruta Samhita. Ayurveda Tattwa Sandipika. Edited by Kaviraja Ambikadutta Shastri. Sharira sthan, Chapter 4, sloka 30. Chaukhambha Prakashani, 2015.

16. Agnivesha. Charaka Samhita, Savimarsha vidyotini, Edited by Pandit Kashinath Shastri, Dr Gorakhnath Chaturvedi. Sharira sthan, Chapter 3, sloka 6. Chaukhambha Prakashani, 2017

17. Sushruta. Sushruta Samhita. Ayurveda Tattwa Sandipika. Edited by Kaviraja Ambikadutta Shastri. Nidan sthan, Chapter 9, sloka 18. Chaukhambha Prakashani, 2015. 
18. Sushruta. Sushruta Samhita. Ayurveda Tattwa Sandipika. Edited by Kaviraja Ambikadutta Shastri. Sharira sthan, Chapter 9, sloka 12. Chaukhambha Prakashani, 2015.

19. Agnivesha. Charaka Samhita, Savimarsha vidyotini, Edited by Pandit Kashinath Shastri, Dr Gorakhnath Chaturvedi. Siddhi sthan, Chapter 9, sloka 4. Chaukhambha Prakashani, 2017

20. Sushruta. Sushruta Samhita. Ayurveda Tattwa Sandipika. Edited by Kaviraja Ambikadutta Shastri. Sharira sthan, Chapter 6, sloka 26. Chaukhambha Prakashani, 2015.

21. Sharangadhar Samhita. Edited by Dr. Bramhanand Tripathi. Purva ardha, Chapter 5, sloka 41. Chaukhambha Prakashani, 2015.

22. Sushruta. Sushruta Samhita. Ayurveda Tattwa Sandipika. Edited by Kaviraja Ambikadutta Shastri. Sutra sthan, Chapter 46, sloka 528. Chaukhambha Prakashani, 2015.

23. Sushruta. Sushruta Samhita. Ayurveda Tattwa Sandipika. Edited by Kaviraja Ambikadutta Shastri. Sharira sthan, Chapter 9, sloka 7. Chaukhambha Prakashani, 2015.

24. Sushruta. Sushruta Samhita. Ayurveda Tattwa Sandipika. Edited by Kaviraja Ambikadutta Shastri. Sharira sthan, Chapter 4, sloka 25. Chaukhambha Prakashani, 2015.

25. Sushruta. Sushruta Samhita. Ayurveda Tattwa Sandipika. Edited by Kaviraja Ambikadutta Shastri. Sharira sthan, Chapter 3, sloka 33. Chaukhambha Prakashani, 2015.

26. Sushruta. Sushruta Samhita. Ayurveda Tattwa Sandipika. Edited by Kaviraja Ambikadutta Shastri. Sharira sthan, Chapter 4, sloka 30. Chaukhambha Prakashani, 2015.

27. Sushruta. Sushruta Samhita. Ayurveda Tattwa Sandipika. Edited by Kaviraja Ambikadutta Shastri. Sutra sthan, Chapter 21, sloka 16. Chaukhambha Prakashani, 2015.

28. Agnivesha. Charaka Samhita, Savimarsha vidyotini, Edited by Pandit Kashinath Shastri, Dr Gorakhnath Chaturvedi. Sharira sthan, Chapter 7, sloka 10. Chaukhambha Prakashani, 2017

29. Sushruta. Sushruta Samhita. Ayurveda Tattwa Sandipika. Edited by Kaviraja Ambikadutta Shastri. Sharira sthan, Chapter 21, sloka 10. Chaukhambha Prakashani, 2015.

30. Sushruta. Sushruta Samhita. Ayurveda Tattwa Sandipika. Edited by Kaviraja Ambikadutta Shastri.
Sharira sthan, Chapter 4, sloka 10. Chaukhambha Prakashani, 2015.

31. Sushruta. Sushruta Samhita. Ayurveda Tattwa Sandipika. Edited by Kaviraja Ambikadutta Shastri. Sutra sthan, Chapter 21, sloka 17. Chaukhambha Prakashani, 2015.

32. Agnivesha. Charaka Samhita, Savimarsha vidyotini, Edited by Pandit Kashinath Shastri, Dr Gorakhnath Chaturvedi. Chikitsa sthan, Chapter 15, sloka 16. Chaukhambha Prakashani, 2017

33. Agnivesha. Charaka Samhita, Savimarsha vidyotini, Edited by Pandit Kashinath Shastri, Dr Gorakhnath Chaturvedi. Sutra sthan, Chapter 24, sloka 24. Chaukhambha Prakashani, 2017

34. Sushruta. Sushruta Samhita. Ayurveda Tattwa Sandipika. Edited by Kaviraja Ambikadutta Shastri. Sharira sthan, Chapter 9, sloka 12. Chaukhambha Prakashani, 2015.

35. Sushruta. Sushruta Samhita. Ayurveda Tattwa Sandipika. Edited by Kaviraja Ambikadutta Shastri. Sharira sthan, Chapter 3, sloka 31. Chaukhambha Prakashani, 2015.

36. Agnivesha. Charaka Samhita, Savimarsha vidyotini, Edited by Pandit Kashinath Shastri, Dr Gorakhnath Chaturvedi. Sutra sthan, Chapter 30, sloka 7. Chaukhambha Prakashani, 2017

37. Agnivesha. Charaka Samhita, Savimarsha vidyotini, Edited by Pandit Kashinath Shastri, Dr Gorakhnath Chaturvedi. Sharira sthan, Chapter 6. Chaukhambha Prakashani, 2017

38. Sushruta. Sushruta Samhita. Ayurveda Tattwa Sandipika. Edited by Kaviraja Ambikadutta Shastri. Sharira sthan, Chapter 6, sloka 7. Chaukhambha Prakashani, 2015.

39. Sushruta. Sushruta Samhita. Ayurveda Tattwa Sandipika. Edited by Kaviraja Ambikadutta Shastri. Sharira sthan, Chapter 6, sloka 9. Chaukhambha Prakashani, 2015.

40. Sushruta. Sushruta Samhita. Ayurveda Tattwa Sandipika. Edited by Kaviraja Ambikadutta Shastri. Sharira sthan, Chapter 4, sloka 31. Chaukhambha Prakashani, 2015.

41. Agnivesha. Charaka Samhita, Savimarsha vidyotini, Edited by Pandit Kashinath Shastri, Dr Gorakhnath Chaturvedi. Chikitsa sthan, Chapter 30, sloka 8-12. Chaukhambha Prakashani, 2017

42. Sushruta. Sushruta Samhita. Ayurveda Tattwa Sandipika. Edited by Kaviraja Ambikadutta Shastri. Sutra 
sthan, Chapter 14, sloka 3. Chaukhambha Prakashani, 2015.

43. Agnivesha. Charaka Samhita, Savimarsha vidyotini, Edited by Pandit Kashinath Shastri, Dr Gorakhnath Chaturvedi. Chikitsa sthan, Chapter 15, sloka 33. Chaukhambha Prakashani, 2017

44. Agnivesha. Charaka Samhita, Savimarsha vidyotini, Edited by Pandit Kashinath Shastri, Dr Gorakhnath Chaturvedi. Chikitsa sthan, Chapter 24, sloka 36. Chaukhambha Prakashani, 2017

45. Agnivesha. Charaka Samhita, Savimarsha vidyotini, Edited by Pandit Kashinath Shastri, Dr Gorakhnath Chaturvedi. Sutra sthan, Chapter 30, sloka 9-11. Chaukhambha Prakashani, 2017

46. Sushruta. Sushruta Samhita. Ayurveda Tattwa Sandipika. Edited by Kaviraja Ambikadutta Shastri. Sharira sthan, Chapter 4, sloka 12. Chaukhambha Prakashani, 2015.

47. Sushruta. Sushruta Samhita. Ayurveda Tattwa Sandipika. Edited by Kaviraja Ambikadutta Shastri. Sharira sthan, Chapter 9, sloka 18. Chaukhambha Prakashani, 2015.

48. Agnivesha. Charaka Samhita, Savimarsha vidyotini, Edited by Pandit Kashinath Shastri, Dr Gorakhnath Chaturvedi. Viman sthan, Chapter 5, sloka 8. Chaukhambha Prakashani, 2017

49. Sushruta. Sushruta Samhita. Ayurveda Tattwa Sandipika. Edited by Kaviraja Ambikadutta Shastri. Sharira sthan, Chapter 9, sloka 12. Chaukhambha Prakashani, 2015.

50. Vriddha Vagbhata. Ashtanga Sangraha. Edited by Dr Ravidutta Tripathi. Sharira sthan, Chapter 6, sloka 18. Chaukhambha Prakashani, 2018.

\section{Source of Support: Nil Conflict of Interest: None Declared}

How to cite this URL: Priyanka Chakraborty et al: A Critical Analysis On The Relationship Between Vrikka, Yakrita And Hridaya In The Pathogenesis Of Vrikka Roga And Its Upadrava W.S.R To Chronic Kidney Disease. International Ayurvedic Medical Journal \{online\} 2021 \{cited September 2021\} Available from: http://www.iamj.in/posts/images/upload/2174_2181.pdf 